\title{
Inhibition of ovulation and LH secretion in the gilt after treatment with ACTH or hydrocortisone
}

\author{
C. R. Barb, R. R. Kraeling, G. B. Rampacek*, E. S. Fonda* and \\ T. E. Kiser* \\ USDA, SEA, Richard B. Russell Agricultural Research Center, P.O. Box 5677, Athens, \\ Georgia 30613, and * Department of Animal and Dairy Science, University of Georgia, Athens, \\ Georgia 30602, U.S.A.
}

\begin{abstract}
Summary. Treatment with ACTH (100 i.u.) or hydrocortisone acetate $(250 \mathrm{mg})$ twice daily for 12 days to increase cortisol concentrations blocked ovulation in all gilts. The preovulatory surge of $\mathrm{LH}$ was also blocked in the treated gilts. Oestrous cycle length and number of days in oestrus were similar for all treatments except that in one of the 2 experiments ACTH suppressed oestrus in 4 of the 5 gilts treated.
\end{abstract}

\section{Introduction}

A relationship between adrenal function and reproductive function has been demonstrated for several species (Christian, 1963; Liptrap, 1970; Ramaley, 1973). Liptrap (1970) demonstrated that treatment with adrenocorticotrophic hormone (ACTH) blocked ovulation, caused cystic ovaries, and delayed oestrus in the pig, whereas hydrocortisone treatment had no effect on ovulation but did delay the onset of oestrus. Schilling \& von Rechenberg (1973) found that treatment with ACTH or flumethasone blocked ovulation in the pig. This effect could be partly overcome by treatment with human chorionic gonadotrophin (hCG), suggesting that luteinizing hormone $(\mathrm{LH})$ secretion may have been altered by the ACTH or flumethasone treatment. This hypothesis is further supported by the results of Liptrap \& Raeside (1968) who reported a decrease in plasma LH concentration in boars following treatment with $\mathrm{ACTH}$, hydrocortisone or prednisolone trimethylacetate. In heifers, treatment with ACTH or hydrocortisone suppressed the preovulatory surge of LH (Stoebel \& Moberg, 1979), and in female rats dexamethasone treatment prevented the preovulatory rise in $\mathrm{LH}$ and reduced pituitary responsiveness to luteinizing hormone releasing hormone (LH-RH) (Baldwin \& Sawyer, 1974).

The purpose of the present experiments was to determine the effects of exogenous ACTH and hydrocortisone acetate on (1) oestrus and ovulation, and (2) the preovulatory surge of LH in the post-pubertal gilt.

\section{Materials and Methods}

\section{Experiment 1}

Fifteen gilts which had displayed one or more oestrous cycles of 18-22 days (onset of oestrus $=$ Day 0 ) were randomly assigned, 5 gilts each, to one of three treatment groups. Control gilts (Group 1) received i.m. injections of corn oil and s.c. injection of $16 \%$ gelatin (Fisher Laboratory grade, Fisher Scientific Co., Norcross, Georgia, U.S.A.). The gilts in Group 2 
received $250 \mathrm{mg}$ hydrocortisone acetate (Sigma Chemical Co., St Louis, Missouri, U.S.A.) suspended in corn oil by i.m. injection and $16 \%$ gelatin s.c. Gilts in Group 3 received 100 i.u. porcine ACTH (grade II, $98 \%$ pure, no detectable LH activity: Sigma) suspended in $16 \%$ gelatin s.c. and corn oil i.m. All gilts were restrained by a snare during the injections which were given twice daily at approximately 08:00 h and 17:00 h for 12 days beginning on Day 14. Oestrus was checked daily at 09:00 h with a boar. The size, type and number of ovarian structures were recorded at laparotomy on the day after the last injection. Ovarian structures with diameters of 8-12 mrn and filled with fluid were classified as preovulatory follicles (Hafez, 1974). Ovarian structures were classified as follicular cysts when the diameter was $>12 \mathrm{~mm}$ and they were fluid filled with little or no luteinization, and as luteal cysts when the diameter was $\geq 10 \mathrm{~mm}$ and luteinization (increased opacity) was pronounced.

Seven additional gilts, at random stages of the oestrous cycle, were used to determine the effects of the treatments on serum cortisol concentrations for a 24-h period. Cannulae were placed into the jugular vein with an 11-gauge thin-walled hypodermic needle without the use of an anaesthetic. Cannulae were secured to the outside of the neck with $7.6 \mathrm{~cm}$-wide elastic bandage wrap. The gilts were treated, as above with ACTH $(\mathrm{N}=2)$, hydrocortisone acetate ( $\mathrm{N}$ $=2)$ or the vehicles $(\mathrm{N}=3) 24 \mathrm{~h}$ after cannulation. Blood samples were collected every $2 \mathrm{~h}$ for the first two sampling periods, and every $3 \mathrm{~h}$ for the remaining $24 \mathrm{~h}$.

\section{Experiment 2}

Twenty gilts which had displayed one or more oestrous cycles of 18-22 days (onset of oestrus $=$ Day 0 ) were moved from outside lots into a group pen in a finishing barn. All gilts were fed a daily dose of $15 \mathrm{mg}$ of an orally active synthetic progestagen: (RU-2267; Regumate: Roussel UCLAF, Paris, France) contained in $2.3 \mathrm{~kg}$ of a corn-soybean meal diet for 18 days to synchronize oestrus (Webel, 1978). Oestrus was checked daily with a boar between 08:00 and 09:00 h throughout the experiment. Following withdrawal of RU-2267, 14 gilts that displayed oestrus within $24 \mathrm{~h}$ of each other were randomly assigned to one of three treatment groups. Group 1 vehicle controls $(\mathrm{N}=4)$, Group 2 hydrocortisone acetate $(\mathrm{N}=5)$ and Group 3 ACTH (purified Cortrophin Gel, no detectable LH activity: Organon, Inc., West Orange, New Jersey, U.S.A.) $(\mathrm{N}=5)$. The treatment schedules were as in Exp. 1, i.e. from Day 14 for 12 days.

On Day 17, gilts were cannulated as in Exp. 1 and placed in individual pens. Starting $24 \mathrm{~h}$ after cannulation, blood samples were collected every $2 \mathrm{~h}$ for the first $24 \mathrm{~h}$ and every hour for an additional $78 \mathrm{~h}$ until Day 22 or for $24 \mathrm{~h}$ after oestrus, whichever came first, except for Gilts 9 and 14 which were bled for an additional $18 \mathrm{~h}$. Serum cortisol and LH concentrations were measured. Gilts were laparotomized the day after the last injection and the size, type and number of ovarian structures were recorded as in Exp. 1.

\section{Hormone assays}

$L H$. A heterologous double-antibody radioimmunoassay was used. Purified porcine $\mathrm{LH}$ was used for iodination (LER-786-3) and standards (LER-778-4). Dose-response curves for pooled porcine serum and increasing concentrations of the $\mathrm{LH}$ standard added to a porcine serum pool were parallel $(P>0.5)$ to the standard curve. The recovery of LH $(0.1-5 \mathrm{ng})$ added to $300 \mu \mathrm{l}$ porcine serum was consistently $110 \pm 4 \%$. Cross-reaction of the antibody with large quantities of other preparations of pituitary hormones $(0 \cdot 1-1000 \mathrm{ng})$ were $2.4 \%$ for FSH (NIH-FSH-P-2), $2.0 \%$ for growth hormone (NIH-GH-P-526B); and $<0.001 \%$ for prolactin (LER-2073). Sensitivity of the assay was $0.1 \mathrm{ng} \mathrm{LH} /$ tube. Intra- and inter-assay coefficients of variation were 8.4 and $10.5 \%$, respectively.

Cortisol. Serum concentrations were determined by radioimmunoassay. A rabbit anticortisol-21-thyroglobulin serum (Miles Research Products, Elkhart, Indiana, U.S.A.; Lot 
No. Cor-2) was diluted 1:10 in 0.01 M-phosphate-buffered (pH 7.0) saline containing $0 \cdot 1 \%$ gelatin (PBSG) which bound approximately $60 \%$ of the $\left[1,2,6,7^{-3} \mathrm{H}\right]$ hydrocortisone (sp. act. 93.1 Ci/mmol: New England Nuclear, Boston, Massachusetts, U.S.A.). A stock cortisol solution (hydrocortisone; Sigma) containing $10 \mathrm{ng}$ cortisol $/ \mathrm{ml}$ ethanol was used to construct a standard curve which ranged from 20 to $2000 \mathrm{pg} /$ tube.

All samples were assayed in duplicate by extracting $200 \mu \mathrm{l}$ serum with $2 \mathrm{ml}$ ethanol. The mixture was vortexed for $1 \mathrm{~min}$, centrifuged at $2000 \mathrm{~g}$ for $15 \mathrm{~min}$ at $4{ }^{\circ} \mathrm{C}$ and $100 \mu \mathrm{l}$ ethanol extract was pipetted into disposable glass test-tubes $(12 \times 75 \mathrm{~mm})$, and the ethanol evaporated in a vacuum oven. Next, $100 \mu \mathrm{l}$ PBSG containing $\left[1,2,6,7^{-3} \mathrm{H}\right]$ hydrocortisone $(0.0072 \mathrm{Ci})$ and $500 \mu \mathrm{l}$ of the anticortisol serum were added to each tube. The tube contents were incubated for $24 \mathrm{~h}$ at $4^{\circ} \mathrm{C}$. Separation of bound from unbound radiolabelled hydrocortisone was achieved by the addition of $500 \mu \mathrm{l} 0.01 \mathrm{M}$-phosphate-buffered saline (pH 7.0) containing $0.625 \%$ norit A (J. T. Baker Chemical Co., Bricktown, New Jersey, U.S.A.) and $0.0625 \%$ dextran T-70 (Pharmacia Fine Chemicals, Piscataway, New Jersey, U.S.A.) and incubated for 15 min at $4^{\circ} \mathrm{C}$. The contents were then centrifuged at $2000 \mathrm{~g}$ for $15 \mathrm{~min}$ at $4^{\circ} \mathrm{C}$. A $500 \mu$ aliquot of the supernatant was placed in a $7-\mathrm{ml}$ counting vial and $5 \mathrm{ml}$ of a counting medium (ScintiVerse, Fisher Scientific Co.) were added. Radioactivity was counted in an Isocap 300 (Tracor Analytic, Atlanta, Georgia, U.S.A.) liquid scintillation counter with a counting efficiency for tritium of approximately $50 \%$.

Extraction efficiency, as determined by addition of radiolabelled hydrocortisone to serum, was $89 \pm 1 \%(n=30)$. Accuracy was evaluated by adding $25,50,75,100,125,150$ and $175 \mathrm{ng}$ cortisol to $1.0 \mathrm{ml}$ pig serum: $26 \cdot 7,60 \cdot 2,80 \cdot 6,107.4,122 \cdot 0,149.6$ and $173.0 \mathrm{ng}$ cortisol were measured, respectively. Aliquots of $200 \mu \mathrm{l}$ luteal-phase pig serum were assayed after ethanol extraction only or after ethanol extraction and Sephadex LH-20 (Pharmacia Fine Chemicals) chromatography to determine the presence of interfering substances. Chromatographic separation of progesterone and 17a-hydroxyprogesterone from cortisol was achieved by using a solvent system consisting of methylene chloride and methanol $(99: 1 \mathrm{v} / \mathrm{v})$ and a packed column of $60 \times 0.7 \mathrm{~mm}$. Mean values of $19.3 \pm 1.0$ and $18.8 \pm 1.0 \mathrm{ng} / \mathrm{ml}(n=4)$ cortisol were determined before and after chromatographic isolation, respectively, and these quantities were not significantly different $(P>0 \cdot 5)$. Serum samples $(200 \mu \mathrm{l})$ were therefore assayed for cortisol without chromatographic isolation. Cross-reactions of the anticortisol serum with $17 \alpha$ hydroxyprogesterone, cortisone, progesterone, corticosterone, testosterone and dihydrotestosterone were $38.5,28.0,11.4,9.6,4.2$ and $0.6 \%$, respectively, and were $<0.01 \%$ for androstenedione, oestradiol, cholesterol, oestrone and pregnenolone. A serum pool containing $70.6 \mathrm{ng}$ cortisol $/ \mathrm{ml}$ was used to determine the precision of the assay. The intra-assay coefficient of variation of 10 duplicate determinations was $7.0 \%$, and the interassay coefficient of variation of 6 assays was $10.7 \%$. Sensitivity of the assay was $20 \mathrm{pg}$ unlabelled cortisol per tube and this was significantly different from zero $(P<0.05)$. Displacement of radiolabelled cortisol by cortisol standards and various amounts of pooled pig serum resulted in regression lines that were not different $(P>0.5)$.

\section{Statistics}

To determine the effects of treatment on the occurrence of oestrus, preovulatory surge of LH and ovulation, data were subjected to $\chi^{2}$ analysis using exact probabilities (Steel \& Torrie, 1960). To evaluate the effect of treatment on oestrous cycle length, number of days in oestrus and ovarian structures, data were subjected to least squares analysis of variance and differences between treatment means were determined by the least significant difference between least square means using the statistical analysis system of Barr, Goodnight, Sall \& Helwig (1976), and pretreatment and post-treatment means (for oestrous cycle length and number days in oestrus) were compared by paired $t$ tests (Steel \& Torrie, 1960). Serum cortisol concentrations 
were analysed by split plot-in-time analysis of variance (Gill \& Hafs, 1971). Serum LH peaks were defined by values that were $50 \%$ greater than the overall mean. The preovulatory surge of $\mathrm{LH}$ was defined by values that were $50 \%$ greater than the overall mean for $\geq 8 \mathrm{~h}$ in succession. Baseline for serum LH was based on all values which were not defined as peak or part of the preovulatory surge of LH. Serum LH concentrations were subjected to one-way analysis of variance (Steel \& Torrie, 1960).

\section{Results}

\section{Experiment 1}

The effects of treatment on follicular development and ovulation are presented in Table 1. Four of the controls exhibited oestrus at the expected time and ovulated as indicated by the presence of CL. The remaining control failed to display a post-treatment oestrus and only small follicles were present. Adrenocorticotrophic hormone and hydrocortisone acetate treatments blocked ovulation in all gilts in Groups 2 and $3(P<0.05)$, but 4 of those in Group 2 exhibited oestrus at the expected time; the ovaries of 3 of these contained predominantly $5-10 \mathrm{~mm}$ follicles and follicular cysts (15-20 mm) were present in the fourth animal. The remaining gilt in Group 2 had only 5-8 mm follicles. Four of the gilts in Group 3 displayed oestrus at the expected time, but the ovaries contained mostly follicular $(15-25 \mathrm{~mm})$ and luteal $(10-15 \mathrm{~mm})$ cysts. However, 2 of these gilts also had two CL each. The remaining gilt in Group 3 failed to display oestrus and only $8-10 \mathrm{~mm}$ follicles were present. Oestrous cycle length $(21 \cdot 3 \pm 0 \cdot 8 ; 21 \cdot 3 \pm 0.4 ; 21 \cdot 5 \pm 0.6$ days) and number of days in oestrus $(2.5 \pm 0.5 ; 3.0 \pm 0.1 ; 2.5 \pm 0.7$ days) were similar for Groups 1,2 and 3 respectively. Serum cortisol concentrations were elevated above control levels $(P<0.05)$ for $24 \mathrm{~h}$ after treatment with hydrocortisone acetate. The increase after ACTH treatment was of a greater magnitude than following hydrocortisone acetate treatment $(P<$ 0.05 ) but serum values decreased to control levels by $10 \mathrm{~h}$ after the last injection (Text-fig. 1).

Table 1. Effects of hydrocortisone acetate (HCA) and ACTH on follicular development and ovulation in gilts

\begin{tabular}{|c|c|c|c|c|c|c|c|c|}
\hline \multirow[b]{2}{*}{ Group } & \multirow[b]{2}{*}{ Treatment } & \multirow{2}{*}{$\begin{array}{l}\text { No. of } \\
\text { gilts }\end{array}$} & \multirow{2}{*}{$\begin{array}{c}\text { No. of } \\
\text { gilts } \\
\text { ovulating }\end{array}$} & \multirow[b]{2}{*}{$\mathrm{CL}$} & \multicolumn{2}{|c|}{ Cysts* } & \multicolumn{2}{|c|}{ Follicles } \\
\hline & & & & & Luteal & Follicular & $4-7 \mathrm{~mm}$ & $8-12 \mathrm{~mm}$ \\
\hline \multicolumn{9}{|c|}{ Experiment I } \\
\hline 1 & Control & 5 & $4^{\mathrm{a}}$ & $8 \cdot 6 \pm 2 \cdot 2^{\mathrm{a}}$ & $0.4 \pm 0.0$ & 0 & $1.2 \pm 1.2$ & 0 \\
\hline 2 & $\mathrm{HCA}$ & 5 & $0^{\mathrm{b}}$ & $\overline{0}^{\mathrm{b}}$ & 0 & $2 \cdot 6 \pm 2 \cdot 4$ & $4 \cdot 6 \pm 2 \cdot 3$ & $0.8 \pm 0.8$ \\
\hline 3 & ACTH & 5 & $0^{\mathrm{b}}$ & $0.8 \pm 0.5^{b}$ & $3.0 \pm 1.9$ & $6 \cdot 4 \pm 3 \cdot 0$ & 0 & $1 \cdot 2 \pm 1 \cdot 2$ \\
\hline \multicolumn{9}{|c|}{ Experiment 2} \\
\hline 1 & Control & 4 & $4^{8}$ & $9 \cdot 8 \pm 1 \cdot 8^{a}$ & $3 \cdot 5 \pm 1 \cdot 9^{a}$ & $0^{\mathrm{a}}$ & $1.0 \pm 1.0$ & $0^{\mathrm{a}}$ \\
\hline 2 & $\mathrm{HCA}$ & 5 & $0^{\mathrm{b}}$ & $0^{\mathrm{b}}$ & $\overline{0}^{\mathrm{b}}$ & $0^{\mathrm{a}}$ & $8.4+4.7$ & $6 \cdot 0 \pm 2 \cdot 2^{b}$ \\
\hline 3 & $\mathrm{ACTH}$ & 5 & $0^{\mathrm{b}}$ & $0^{\mathrm{b}}$ & $0^{\mathrm{b}}$ & $8 \cdot 0 \pm 4 \cdot 8^{b}$ & $5.2 \pm 4.7$ & $0^{\mathrm{a}}$ \\
\hline
\end{tabular}

Values are mean \pm s.e.m.

Means within a column with different superscripts are significantly different $(P<0.05)$.

* Total no. of cysts for Group 3 gilts in Exp. 1 was greater $(P<0.05)$ than the values for gilts in Groups 1 and 2.

\section{Experiment 2}

The effects on follicular development and ovulation are presented in Table 1. All control gilts expressed oestrus and ovulated. Four of the gilts in Group 2 exhibited oestrus at the expected time, but none ovulated, although follicles $5-12 \mathrm{~mm}$ in diameter were present. The other gilt in Group 2 did not exhibit oestrus and had only $4-5 \mathrm{~mm}$ follicles. Four of the gilts in Group 3 failed to display oestrus and none of the 5 gilts in this group ovulated. The ovaries contained 


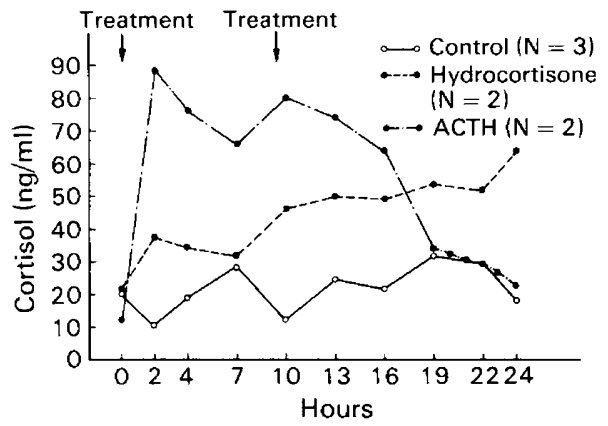

Text-fig. 1. Serum cortisol concentrations in gilts (Exp. 1) for $24 \mathrm{~h}$ after treatment with hydrocortisone acetate (Group 2), ACTH (Group 3) or vehicles only (Group 1). The last 2 treatment injections are shown by arrows.

mostly follicular cysts $(15-25 \mathrm{~mm})(\mathrm{N}=3)$ or $4-7 \mathrm{~mm}$ follicles $(\mathrm{N}=2)$. Oestrous cycle length $(20.8 \pm 0.9 ; 21.0 \pm 0.6$ days $)$ and number of days in oestrus $(1.5 \pm 0.3 ; 2.3 \pm 0.3$ days $)$ were similar for gilts in Groups 1 and 2.

Serum cortisol concentrations were significantly elevated in Groups 2 and 3 (Text-fig. 2). In Group 2 concentrations were higher than those in Group $1(P<0.05)$ throughout the treatment period, but values in Group 3 gilts fluctuated markedly to give a mean level higher than those in Groups 1 and 2 (Text-fig. 2). The extreme fluctuations in serum cortisol concentrations in the ACTH-treated gilts followed the injection schedule. Peak serum cortisol concentrations following ACTH treatment were greater in Exp. $2(150 \mathrm{ng} / \mathrm{ml})$ than in Exp. $1(90 \mathrm{ng} / \mathrm{ml})$, but we have no explanation for this difference.

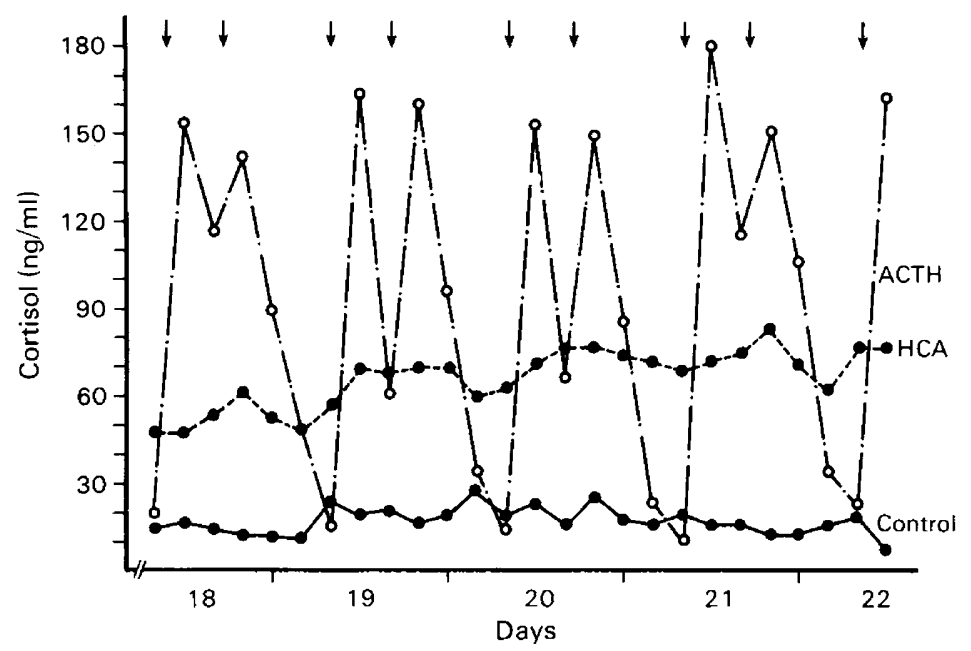

Text-fig. 2. Serum cortisol concentrations on Days 18-22 of the oestrous cycle of gilts (Exp. 2) treated with vehicle only (Group 1) hydrocortisone acetate (HCA; Group 2) or ACTH (Group 3 ). The times of treatment injections (see text) are shown by arrows.

Serum LH concentrations are shown in Text-fig. 3. A preovulatory surge of LH ranging from 3.7 to $10.9 \mathrm{ng} / \mathrm{ml}$ coincided with or occurred within $24 \mathrm{~h}$ of oestrus in the control gilts in Group 1 and was elevated for an average of $11.8 \pm 1.4 \mathrm{~h}$. Gilt 1 exhibited oestrus on Day 23, the day after the last sampling period and the preovulatory LH surge detected on Day 22 for this gilt may not have been characterized in its entirety. Apart from the surge values, serum LH remained low $(0.6-3.0 \mathrm{ng} / \mathrm{ml})$ throughout the sampling period. Treatments with hydrocortisone 


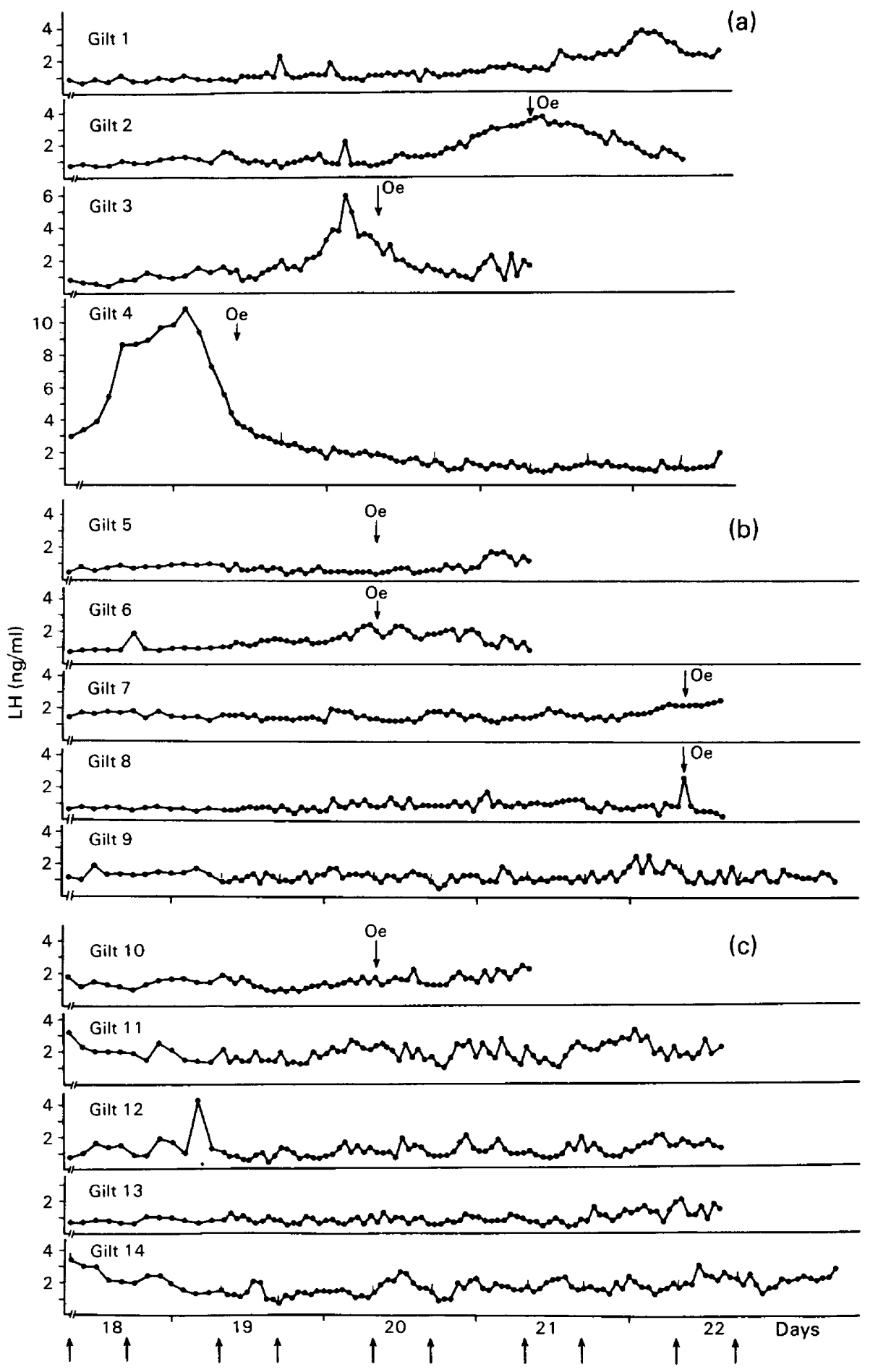

Text-fig. 3. Serum LH concentrations on Days 18-22 of the oestrous cycle of gilts (Exp. 2) treated with (a) vehicles only-Group 1, (b) hydrocortisone acetate-Group 2, or (c) ACTH-Group 3. The times of treatment injections are shown by arrows. $\mathrm{Oe}=$ oestrus. 
acetate or ACTH blocked the preovulatory surge of LH (Text-fig. 3) in all gilts $(P<0.05)$. Serum LH concentrations ranged from 0.4 to $2.6 \mathrm{ng} / \mathrm{ml}$ in Group 2 gilts (Text-fig. $3 \mathrm{~b}$ ) and from 0.4 to $3.4 \mathrm{ng} / \mathrm{ml}$ in Group 3 gilts (Text-fig. $3 \mathrm{c}$ ).

\section{Discussion}

These results indicate that hydrocortisone acetate either suppressed development of preovulatory follicles or that the preovulatory follicles present on Day 20 may have become atretic, and that ACTH failed to inhibit follicular growth. This may have been the result of extreme fluctuations in serum cortisol concentrations in the ACTH-treated gilts (Text-fig. 2) allowing for growth and development of follicles which became cystic when ovulation did not occur. Liptrap (1970) reported that treatment with $500 \mathrm{mg}$ hydrocortisone acetate daily from Day 14 to the end of oestrus had no effect on ovulation in the pig. This may have been the result of two factors. First, a once-daily injection schedule may have failed to maintain chronic elevation of cortisol for a 24-h period, thus allowing a rebound in gonadotrophin secretion. Secondly, treatment with hydrocortisone acetate was terminated at the end of oestrus and the ovaries were not examined until $2-3$ days later.

Oestrous cycle length and number of days in oestrus were similar for all treatments in Exp. 1. This is inconsistent with the results of Liptrap (1970), who found that treatment with ACTH or hydrocortisone delayed the onset of oestrus in sows. Stoebel \& Moberg (1979) demonstrated that ACTH or hydrocortisone treatment prevented the expression of oestrus in heifers. However, in Exp. 2 ACTH treatment suppressed oestrus in 4 of the 5 gilts. The higher serum cortisol concentrations following ACTH treatment in Exp. 2 could have suppressed behavioural oestrus (Text-fig. 2). Close \& Liptrap (1975) indicated that plasma progesterone concentration reached a peak at $4-5 \mathrm{ng} / \mathrm{ml}$ within $2 \mathrm{~h}$ after treatment with $100 \mathrm{i}$.u. ACTH and dropped to $1 \mathrm{ng} / \mathrm{ml}$ by 4 $\mathrm{h}$ in ovariectomized sows. Coryn, Spincemaille \& Vandeplassche (1979) have demonstrated that once serum progesterone concentrations have fallen below $5 \mathrm{ng} / \mathrm{ml}$ ovulation can be expected within 4 days. Therefore, it is unlikely that progesterone of adrenal origin suppressed behavioural oestrus in the present study.

The magnitude, duration and occurrence of the preovulatory surge of LH in the control gilts were consistent with previous observations for gilts (Niswender, Reichert \& Zimmerman, 1970; Rayford, Brinkley \& Young, 1971; Henricks, Guthrie \& Handlin, 1972). However, baseline serum LH in the gilts treated with hydrocortisone $(1.2 \pm 0.2 \mathrm{ng} / \mathrm{ml})$ and ACTH $(1.4 \pm 0.2$ $\mathrm{ng} / \mathrm{ml})$ were similar to controls $(1.4 \pm 0.1 \mathrm{ng} / \mathrm{ml})$, indicating that both treatments failed to block pituitary LH secretion completely. Glucocorticoids may alter LH secretion by acting at the central nervous system and/or pituitary level. Liptrap \& Raeside (1968) and Liptrap (1973) suggested that the effect of ACTH on plasma LH levels in the boar and induction of cystic ovaries in the sow were due to secretion of adrenocortical steroids because adrenalectomy abolished the effect of ACTH in both cases. Hagino, Watanabe \& Goldzieher (1969) demonstrated that hypothalamic implants of glucocorticoids inhibited PMSG-induced ovulation in the immature rat, presumably by inhibiting the positive feedback stimulus of ovarian hormones and resulting in suppression of gonadotrophin secretion. Similarly, in the pig, treatment with hydrocortisone or ACTH suppressed the rise in oestrogen secretion during the follicular phase of the cycle, resulting in possible inhibition of positive feedback stimulus of oestrogen on LH secretion (Liptrap, 1970). Smith, Johnson, Weick, Levine \& Davidson (1971) also reported that implantation of crystalline cortisol in the medial basal hypothalamus suppressed ovarian and uterine development and prevented ovulation in immature female rats; it was concluded that cortisol suppressed gonadotrophin secretion at the hypothalamo-pituitary level. In adult rats, systemic administration of dexamethasone prevented the preovulatory surge of LH and diminished the pituitary response to exogenous LH-RH (Baldwin \& Sawyer, 1974). Similarly, suppression of LH secretion in response to exogenous LH-RH in humans treated 
chronically with prednisolone has been reported by Sakakura, Takebe \& Nakagawa (1975). Therefore, the effects of hydrocortisone and ACTH treatment on the preovulatory surge of LH in gilts may be the result of a decrease in pituitary responsiveness to LH-RH and/or a decrease in the secretion of LH-RH from the hypothalamus. The results of this experiment are in agreement with the work of Stoebel \& Moberg (1979) which showed that both hydrocortisone and $\mathrm{ACTH}$ treatment suppressed the preovulatory surge of $\mathrm{LH}$ in heifers and the work of Baldwin (1979) indicating that chronic elevation of plasma cortisol levels in rats resulted in depression of the pro-oestrous rise of $\mathrm{LH}$.

In summary, these results indicate that treatment with hydrocortisone or ACTH suppressed the preovulatory surge of LH and subsequent ovulation. Suppression of the preovulatory surge of LH may have inhibited follicular development, suppressed the preovulatory rise in oestrogens, increased follicular atresia and/or caused cyst formation. Therefore, hypersecretion of hydrocortisone or ACTH due to various stressful stimuli could suppress the preovulatory surge of $\mathrm{LH}$, block ovulation and alter normal reproduction in the gilt.

Mention of a trade name, proprietary product or specific equipment does not constitute a guarantee or warranty by the USDA and does not imply its approval to the exclusion of other products which may be suitable.

\section{References}

Baldwin, D.M. (1979) The effects of glucocorticoids on estrogen dependent luteinizing hormone release in the ovariectomized rat and on gonadotropin secretion in the intact female rat. Endocrinology 105, 120-128.

Baldwin, D.M. \& Sawyer, C.H. (1974) Effects of dexamethasone on LH release and ovulation in the cyclic rat. Endocrinology 94, 1397-1403.

Barr, A.J., Goodnight, J.H., Sall, J.P. \& Helwig, J.T. (1976) A User's Guide to SAS 76. North Carolina State University, Raleigh.

Christian, J.J. (1963) Endocrine adaptive mechanisms and the physiologic regulation of population growth. Physiol. Mammal. 1, 189-353.

Close, R.W. \& Liptrap, R.M. (1975) Plasma progesterone levels in sows with induced cystic ovarian follicles. Res. vet. Sci. 19, $28-34$.

Coryn, M., Spincemaille, J. \& Vandeplassche, M. (1979) Estrous cycle, pregnancy and parturition in the mare, cow and sow: progesterone and estrogens. Annls Endocr. 40, 511-512.

Gill, J.L. \& Hafs, H.D. (1971) Analysis of repeated measurements of animals. J. Anim. Sci. 33, 331-336.

Hafez, E.S.E. (1974) Functional anatomy of female reproduction. In Reproduction of Farm Animals, pp. 24-58. Ed. E. S. E. Hafez. Lea and Febiger, Philadelphia.

Hagino, N., Watanabe, M. \& Goldzieher, J.W. (1969) Inhibition by adrenocorticotrophin of gonadotrophin-induced ovulation in immature female rats. Endocrinology 84, 308-314.

Henricks, D.M., Guthrie, H.D. \& Handlin, D.L. (1972) Plasma estrogens, progesterone and luteinizing hormone levels during the estrous cycle in pigs. Biol. Reprod. 6, 210-218.

Liptrap, R.M. (1970) Effects of corticotrophin and corticosteroids on oestrus, ovulation and oestrogen excretion in the sow. $J$. Endocr. 47, 197-205.

Liptrap, R.M. (1973) Oestrogen excretion by sows with induced cystic ovarian follicles. Res. vet. Sci. 15, 215-219.
Liptrap, R.M. \& Raeside, J.I. (1968) Effects of corticotrophin and corticosteroids on plasma interstitial cell-stimulating hormone and urinary steroids in the boar. J. Endocr. 42, 33-43.

Niswender, G.D., Reichert, L.E., Jr \& Zimmerman, D.R. (1970) Radioimmunoassay of serum levels of luteinizing hormone throughout the estrous cycle in the pig. Endocrinology 87, 576-583.

Ramaley, J.A. (1973) Role of the adrenal in PMSinduced ovulation before puberty: effect of adrenalectomy. Endocrinology 92, 881-887.

Rayford, P.L., Brinkley, H.J. \& Young, E.P. (1971) Radioimmunoassay determination of LH concentrations in the serum of female pigs. Endocrinology 88, 707-713.

Sakakura, M., Takebe, K. \& Nakagawa, S. (1975) Inhibition of luteinizing hormone secretion induced by synthetic LRH by long-term treatment with glucocorticoids in human subjects. J. clin. Endocr. Metcb. 40, 774-779.

Schilling, E. \& von Rechenberg, W. (1973) Function of the adrenal cortex and the process of ovulation in the pig. Zentbl. VetMed. A. 20,705-717.

Smith, E.R., Johnson, J., Weick, R.F., Levine, S. \& Davidson, J.M. (1971) Inhibition of the reproductive system in immature rats by intracerebral implantation of cortisol. Neuroendocrinology 8, 94-106.

Steel, R.G.D. \& Torrie, J.H. (1960) Principles and Procedures of Statistics. McGraw-Hill, New York.

Stoebel, D.P. \& Moberg, G.P. (1979) Effect of ACTH and cortisol on estrus behavior and the luteinizing hormone surge in the cow. Fedn Proc. Fedn Am. Socs. Exp. Biol. 38, 1254, Abstr.

Webel, S.K. (1978) Ovulation control in the pig. In Control of Ovulation, pp. 421-434. Eds D. B. Crighton, N. B. Haynes, G. R. Foxcroft \& G. E. Lamming. Butterworths, London. 